\title{
EchoGéo
}

$13 \mid 2010$

Afrique, 50 ans d'indépendance : État et territoires

\section{The struggle for the Warwick Market in Durban}

\section{Brij Maharaj}

\section{OpenEdition}

Journals

Édition électronique

URL : https://journals.openedition.org/echogeo/12043

DOI : 10.4000/echogeo. 12043

ISSN : 1963-1197

\section{Éditeur}

Pôle de recherche pour l'organisation et la diffusion de l'information géographique (CNRS UMR 8586)

Référence électronique

Brij Maharaj, «The struggle for the Warwick Market in Durban », EchoGéo [En ligne], 13 | 2010, mis en ligne le 20 septembre 2010, consulté le 03 août 2021. URL : http://journals.openedition.org/echogeo/ 12043 ; DOI : https://doi.org/10.4000/echogeo.12043

Ce document a été généré automatiquement le 3 août 2021

EchoGéo est mis à disposition selon les termes de la licence Creative Commons Attribution - Pas d'Utilisation Commerciale - Pas de Modification 4.0 International (CC BY-NC-ND) 


\section{The struggle for the Warwick Market in Durban}

\section{Brij Maharaj}

Picture 1 - Protest of the Early Morning Market Support Group in May-June 2009

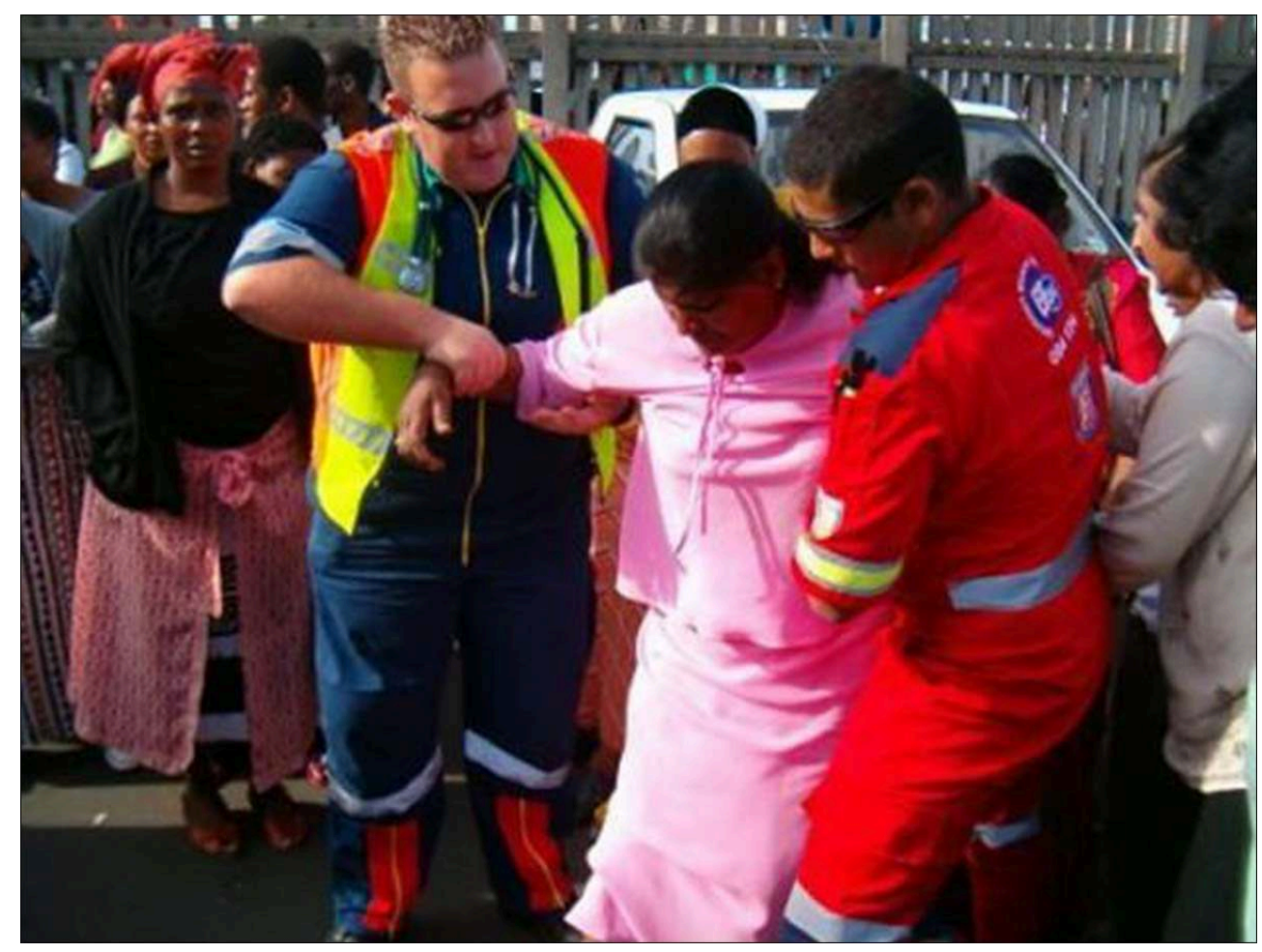

Author: Roy Chetty, Mai-June 2009.

1 The Warwick Avenue Triangle (WAT), an inner city community, and one of the oldest mixed residential areas in Durban, defied the apartheid state's strategies to destroy it. Slum clearance laws, the Group Areas Act, and urban renewal programmes were used to try to destroy the community. 
2 It would appear that in the post-apartheid era, the Durban Metro is attempting to succeed where apartheid failed. The public outcry against the Durban Metro's plans to replace the historic market with a mall, displace poor traders from the Warwick Avenue area and deny them their livelihoods reveal significant continuities between the apartheid and democratic eras.

3 The Warwick Market is suitably located for low income residents and workers, being contiguous to public transport facilities and the market, and was bounded by the Western Freeway, Berea Road and Warwick Avenue. It represented the "city centre" for the majority of the low income people in the Durban area.

4 The essence of the city's case for the destruction of the market and the construction of a mall was that: the present site was a dirty, disruptive and "illegal" blot on a modern city (very much similar to the "sanitation syndrome" of the apartheid era which equated contact with blacks with disease and contamination); and the public-private partnership with the mall developers would improve the transport infrastructure in the area.

5 According to City Manager and Deputy Mayor, those who were opposing the development of the mall in Warwick Avenue were variously: preventing poor people from enjoying the privileges associated with malls; pursuing narrow, ethnic, racist agendas; opposing a "golden opportunity for investment"; opposing the democratic majority; and wanting the traders to remain "trapped in the second economy".

6 The sustained public outcry and opposition to the destruction of the iconic early morning market and the forced relocation of traders has been unprecedented in democratic South Africa. It has also re-invigorated critical public debate and dissent in Durban.

7 Traders, street vendors, unions, civics, NGOS, architects, planners, academics and researchers have been united in condemning the destruction and displacement as this would adversely affect the livelihoods and heritage of black communities in the city.

While the poor and the disadvantaged in Warwick Avenue were largely marginalized through limited participatory opportunities, a positive outcome in opposing relocation has been the emergence of non-racial solidarity, a bane to those who demonstrate a callous disregard for the needs of the poor, and who are used to defending mediocrity.

\section{BIBLIOGRAPHIE}

Maharaj B., 1999. The Integrated Community Apartheid Could Not Destroy: the Warwick Avenue Triangle in Durban. Journal of Southern African Studies, 25(2), 249-266. http:// www.millersville.edu/ schaffer/courses/su2003/soc329/Maharaj.pdf

Sutcliffe M., 2009. Warwick Mall will Benefit All. The Mercury, 3 June 2009.

Sutcliffe M., 2009. Now that academics are awake it is time that they learnt the facts. The Mercury, 15 June 2009. 
Skinner C., 2009. Challenging city imaginaries : Street traders' struggles in Warwick Junction. Agenda 81, 2009, p. 101-109. http://www.streetnet.org.za/wp-content/uploads/2010/06/ Agenda82Carolineskinner.pdf

\section{AUTEUR}

BRIJ MAHARAJ

University of KwaZulu-Natal, Pietermaritzburg, South Africa, maharajb@ukzn.ac.za 